\title{
Short communication: Planning considerations for on-farm dairy processing enterprises
}

\author{
S. M. Smith, E. A. Chaney, and J. M. Bewley ${ }^{1}$ \\ Department of Animal and Food Sciences, University of Kentucky, Lexington 40546
}

\section{ABSTRACT}

Across the world, more dairy producers are considering on-farm dairy processing to add value to the milk produced on their farms. Dairy producers may bottle milk or process their milk into cheese, ice cream, butter, yogurt, or cream. The primary objective of this research was to establish a series of sound factors or indicators of success for those considering on-farm processing. A survey was employed to collect opinions and advice from managers of on-farm processing enterprises. Surveys were distributed online $(\mathrm{n}=120)$, with 31 surveys returned, accounting for a $25.8 \%$ response rate. Most (64\%) respondents had been involved in on-farm dairy processing for less than $10 \mathrm{yr}$. Sixty-one percent of respondents attained a positive cash flow in 1 to 3 yr. The primary products manufactured were cheese (69\%), milk (59\%), ice cream (31\%), yogurt (25\%), and butter $(21 \%)$. Factors influencing the decision to start an on-farm dairy processing enterprise included commodity milk prices (61\%), desire to work with the public (41\%), an opportunity to promote the dairy industry $(39 \%)$, a desire to maintain or expand a small family operation (29\%), and product differentiation (16\%). Respondents cited dealing with regulations (26\%), product marketing (19\%), manufacturing technicalities $(19 \%)$, and securing funding $(17 \%)$ as the most difficult parts of starting the business. Open-ended responses provided by the respondents of this survey were also documented to give future dairy producers advice. The most common advice to future on-farm processors was to work on realistic business plans, develop and follow realistic budgets, and observe and use market surveys within the industry. These results provide a useful array of information for future on-farm dairy processing enterprises.

Key words: on-farm dairy processing, survey, dairy extension

Received December 31, 2012.

Accepted March 16, 2013.

${ }^{1}$ Corresponding author: jbewley@uky.edu

\section{Short Communication}

Dairy producers may bottle milk or process milk at the farm into products such as cheese, ice cream, butter, yogurt, or cream. Proper planning is necessary to establish a successful on-farm dairy processing enterprise. However, those individuals interested in beginning an on-farm dairy processing facility may find limitations within the resource materials available. Economic success in processing depends on individual business, financial management, and marketing skills, whether it is within a large or small-scale on-farm dairy processing facility (Becker et al., 2007).

Each product requires its own specific manufacturing guidelines, resources, and capital investments. Programming models have been developed to help processors evaluate the economics of manufacturing dairy products. When producing cheese, for example, a program model has been developed to maximize net revenue in cheese manufacturing. This model demonstrated that the net revenue varied as milk resource prices and composition varied. It showed that Mozzarella net revenue was much higher than Cheddar while the price of cream was high, and that cheese plants that did not optimize the use of resources in response to these variations in prices and composition missed a large profit margin opportunity (Papadatos et al., 2002). Frank (2000) developed a budget model specifically for on-farm dairy processors.

On-farm dairy processors should evaluate consumer and market trends to determine which products to produce. Understanding what prices to sell processed products for is also important. One must understand what price the market will bear, what prices competing products are sold for, and what forces will affect market price. Product prices are also affected by product quality and market reputation. Additionally, the factors that affect market prices vary by product. For example, when producing ice cream, price and consumer income are the main determinants of ice cream product demand (Davis et al., 2009). Market trends are key factors in future financial success. Research in these areas can benefit the on-farm dairy processor. For example, a simulation model is available to forecast retail 
Table 1. Distributions of years involved in on-farm dairy processing and time to attain a positive cash flow among respondents to a national on-farm dairy processing survey

\begin{tabular}{lc}
\hline Item & $\begin{array}{c}\text { Percentage of } \\
\text { respondents }\end{array}$ \\
\hline Number of years involved in on-farm dairy & \\
processing & 9 \\
$<1$ & 29 \\
1 to 5 & 26 \\
5 to 10 & 19 \\
10 to 15 & 16 \\
$>15$ & \\
Time to attain positive cash flow & 12.5 \\
No cash flow yet & 9.5 \\
$<6$ mo & 19 \\
6 mo to 1 yr & 32 \\
1 to 3 yr & 19 \\
3 to 5 yr & 6 \\
5 to 10 yr &
\end{tabular}

demands for fluid milk and cheese and the supply and price of farm milk over the next decade (Schmit and Kaiser, 2006). Other important considerations for onfarm dairy processors include environmental impacts and water use (Milani et al., 2011), advertisement and marketing expenses and strategies (Klotz, 2002), assembly and distribution (Roth et al., 2008), physical assets required, and food safety and quality guidelines (Hoge and Newcomer, 1998; Zhao and Hirsch, 2002; Turner, 2003). Education also plays an important role. Education on dairy production ranges from students and extension land-grant research universities (Kensinger and Muller, 2006) to farmers and large-scale industry leaders (Gherty, 1995).

The primary objective of this research was to establish a series of sound factors or indicators of success for those considering on-farm processing. A survey was used to collect opinions and advice from managers of on-farm processing enterprises. An extensive online internet search was conducted to identify the specific dairy value-added processors in all 50 of the US states. An electronic survey was distributed to 120 dairy valueadded processors in March 2010. A web-based survey tool, Key Survey (WorldAPP, Braintree, MA), was used to distribute surveys and compile data. The survey comprised questions focused on cash flow, financing, sources of information used to start a business, and advice given to prospective business owners. The survey consisted of 12 questions. Thirty-one surveys were completed (25.8\% response rate). Admittedly, this is a small sample size and may not represent the views of all on-farm processors. However, the results of the survey do provide a compilation of advice to future on-farm dairy processors. Data were entered into and descriptive statistics were analyzed in Excel (Microsoft Corp., Redmond, WA).

Longevity in the business (Table 1) was distributed as follows: $<1$ yr (9\%), 1 to 5 yr (29\%), 5 to 10 yr $(26 \%)$, 10 to 15 yr (19\%), and $>15$ yr (16\%). This range indicates a wide distribution of experience among survey respondents. The time needed to attain positive cash flow varied tremendously among survey respondents (Table 1). Although $81.5 \%$ of respondents indicated a positive cash flow was attained within $5 \mathrm{yr}, 12.5 \%$ had not attained a positive cash flow at the time of the survey. Cheese $(69 \%)$, milk $(59 \%)$, ice cream $(31 \%)$, yogurt $(25 \%)$, and butter $(21 \%)$ were the most common products manufactured on farm (Table 2). Buttermilk, cream, and crème fraîche were also mentioned as manufactured products.

Funding needed to start the business (Table 3) was obtained from loans (68\%), personal savings (59\%), family loans or gifts (45\%), and grants (35\%). Factors influencing the decision to start the business venture (Table 3) included commodity milk prices (61\%), desire to work with the public (41\%), opportunity to promote the dairy industry (39\%), desire to maintain or expand

Table 2. Types and sources of manufactured dairy products by respondents to a national on-farm dairy processing survey

\begin{tabular}{lc}
\hline Item & $\begin{array}{c}\text { Percentage of } \\
\text { respondents }\end{array}$ \\
\hline Product & \\
Cheese & 69 \\
Milk & 59 \\
Ice cream & 31 \\
Yogurt & 25 \\
Butter & 21 \\
Buttermilk & 2 \\
Cream & 2 \\
Crème fraîche & 2 \\
Source of milk for manufactured products & 2 \\
Use only milk from individual's personal farm & 74 \\
Combination of milk from individual's personal farm and other farms or suppliers & 22 \\
Milk purchased from other farms or suppliers & 2 \\
\hline
\end{tabular}


Table 3. Summary of responses to questions related to starting a new enterprise from on-farm dairy processors responding to a national on-farm dairy processing survey

\begin{tabular}{|c|c|}
\hline Item & $\begin{array}{l}\text { Percentage of } \\
\text { respondents }\end{array}$ \\
\hline \multicolumn{2}{|l|}{ Funding sources used to finance business } \\
\hline Loans & 68 \\
\hline Personal savings & 59 \\
\hline Family loans or gifts & 45 \\
\hline Grants & 35 \\
\hline Income from another enterprise or business & 7 \\
\hline \multicolumn{2}{|l|}{ Factors influencing decision to start enterprise } \\
\hline Commodity milk prices & 61 \\
\hline Desire to work with the public & 41 \\
\hline Opportunity to promote the dairy industry & 39 \\
\hline Desire to maintain or expand a small family operation & 29 \\
\hline Differentiation of product (e.g., sustainable, locally grown, organic) & 16 \\
\hline \multicolumn{2}{|l|}{ Most difficult part of starting business } \\
\hline Dealing with regulations & 26 \\
\hline Product marketing & 19 \\
\hline Manufacturing technicalities & 19 \\
\hline Securing funding & 17 \\
\hline Creating a business plan & 7 \\
\hline Balancing everything & 7 \\
\hline Labor availability and training & 3.5 \\
\hline Locating equipment & 3.5 \\
\hline \multicolumn{2}{|l|}{ Information sources } \\
\hline Existing processors & 88 \\
\hline Books & 64 \\
\hline Internet & 58 \\
\hline Local or regional meetings & 39 \\
\hline Cooperative extension service & 32 \\
\hline Stage agencies & 19 \\
\hline Video tapes/DVDs & 8 \\
\hline Veterinarian & 3 \\
\hline Customers & 3 \\
\hline Equipment manufacturers & 3 \\
\hline Commodity organizations & 3 \\
\hline \multicolumn{2}{|l|}{ Satisfaction with decision to start an on-farm dairy processing enterprise } \\
\hline Extremely satisfied & 52 \\
\hline Satisfied & 45 \\
\hline Neutral & 3 \\
\hline Dissatisfied & 0 \\
\hline Extremely dissatisfied & 0 \\
\hline
\end{tabular}

a family business (29\%), and desire to differentiate a product $(16 \%)$. These results demonstrate the range of goals on-farm dairy processors may have and may indicate some of the challenges these business managers face in meeting multiple goals. When asked to describe the most difficult part of starting the business (Table 3 ), the most frequently cited challenge was dealing with regulations $(26 \%)$ followed by product marketing (19\%), manufacturing technicalities (19\%), and securing funding $(17 \%)$. Each of these areas represents a challenge that a dairy farm selling their milk to a commodity market would not have. The most frequently cited sources of information used in developing the business (Table 3) were existing processors (87\%), books $(65 \%)$, the Internet (58\%), local or regional meetings (39\%), the cooperative extension service $(32 \%)$, and stage agencies (19\%). The reliance on existing processors for information reflects the tight-knit community of on- farm dairy processors and the lack of resources to help outside of existing processors.

When producers were asked, "If you had it to do all over again, would you do it again"? 84\% of respondents replied "yes." This response further emphasizes the importance of research in on-farm dairy processing facilities, given the apparent satisfaction with the decision. Most respondents indicated they were either extremely satisfied $(52 \%)$ or satisfied $(45 \%)$ with their decision to start on-farm dairy processing, whereas $3 \%$ of respondents were neutral (Table 3 ).

When asked for advice to future processors, common themes included market research, business plans, marketing, seeking advice from existing processors, and thorough planning (Table 4). The list of advice to future on-farm processors in Table 4 provides a comprehensive compilation of experience for future on-farm processors. These suggestions also point out the importance of set- 
Table 4. Responses from on-farm dairy processors responding to a national on-farm dairy processing survey when asked to answer "What advice do you have for others considering on-farm dairy processing?"

\begin{tabular}{lr}
\hline Advice & $\mathrm{n}$ \\
\hline Work on realistic business plans, budgets, and market surveys & 10 \\
Seek out other successful processors and learn from them & 6 \\
Conduct thorough research for every aspect of the business & 6 \\
Have a large enough population in your area to support a long-term market for your products & 5 \\
Be prepared for long hours and hard work & 5 \\
Have a thorough understanding of processing and sanitation regulations & 5 \\
Have strong family support and labor & 4 \\
Do not plan to get rich and support a dairy that is not making a profit & 3 \\
Develop and promote unique, quality, branded niche products & 3 \\
Just because you want to do it does not mean it is for you, because it is a commitment to a different lifestyle & 2 \\
Time management is an important consideration & 2 \\
Be open minded to complementary business ventures or products & 2 \\
Be patient, determined, and perseverant & 2 \\
Focus on good customer service & 2 \\
Establish a fair price for your product & 2 \\
You need to have strong contingency financing & 1 \\
Know how to select, hire, train, and retrain staff & 1 \\
Be very sure you enjoy inviting guests to your farm & 1 \\
Know where you can sell your product & 1 \\
Focus on direct sales as much as possible (farmers markets) & \\
Be very involved and thorough in building the facility; make sure it is built for a high-humidity, wet situation with proper ventilation & 1 \\
and floors that actually slope to the drain &
\end{tabular}

ting realistic income expectations. Moreover, they demonstrate that the transition from managing dairy cows to dairy products involves a completely new skill set. Results of this research may be of help to future dairy producers wishing to establish on-farm dairy processing enterprises.

\section{ACKNOWLEDGMENTS}

The authors of the survey thank the on-farm dairy processors who allowed us to conduct this survey as well as Eunice Schlappi (Kentucky Department of Agriculture, Frankfort), Denise Jones (Kentucky Dairy Development Council, Loretto), Tess Caudill (Kentucky Department of Agriculture, Frankfort), and Julia Hofmeister (University of Kentucky, Lexington) for their help in developing the survey questions.

\section{REFERENCES}

Becker, K. M., R. L. Parsons, J. Kolodinsky, and G. N. Matiru. 2007. A cost and returns evaluation of alternative dairy products to determine capital investment and operational feasibility of a smallscale dairy processing facility. J. Dairy Sci. 90:2506-2516.
Davis, C. G., D. P. Blayney, S. T. Yen, and J. Cooper. 2009. An analysis of at-home demand for ice cream in the United States. J. Dairy Sci. 92:6210-6216

Frank, G. 2000. You can make it, you can sell it, but can you "make it" selling it? The University of Wisconsin Center for Dairy Profitability. Accessed Dec. 31, 2012. http://cdp.wisc.edu/pdf/onfarm.pdf.

Gherty, J. 1995. Serving the customer! Education's challenge for the future. J. Dairy Sci. 78:1399-1406.

Hoge, P. M., and C. Newcomer. 1998. Frozen dessert processing. DPC 61. The Dairy Practices Council, Richboro, PA.

Kensinger, R. S., and L. D. Muller. 2006. Major advances in teaching dairy production. J. Dairy Sci. 89:1155-1162.

Klotz, J.-C. V. 2002. How to direct-market farm products on the Internet. US Department of Agriculture, Agricultural Marketing Service, Transportation and Marketing Programs, Marketing Services Branch, Washington, DC.

Milani, F. X., D. Nutter, and G. Thoma. 2011. Invited review: Environmental impacts of dairy processing and products: A review. J. Dairy Sci. 94:4243-4254.

Papadatos, A., A. M. Berger, J. E. Pratt, and D. M. Barbano. 2002. A nonlinear programming optimization model to maximize net revenue in cheese manufacture. J. Dairy Sci. 85:2768-2785.

Roth, S. A. G., J. Hyde, and B. Kelly. 2008. Get more from your milk: Increasing profit through value-added products. Accessed Dec. 31 2012. http://pubs.cas.psu.edu/freepubs/pdfs/xa0019.pdf.

Schmit, T. M., and H. M. Kaiser. 2006. Forecasting fluid milk and cheese demands for the next decade. J. Dairy Sci. 89:4924-4936.

Turner, R. 2003. On-farm and small-scale dairy products processing. DPC 90. The Dairy Practices Council, Richboro, PA.

Zhao, Y., and D. W. Hirsch. 2002. Food safety in farmstead cheesemaking. DPC 100. The Dairy Practices Council, Richboro, PA. 